Article

\title{
Comparative Analysis between Dynamic and Quasi-Steady-State Methods at an Urban Scale on a Social-Housing District in Venice
}

\author{
Tiziano Dalla Mora ${ }^{1}$ (D), Lorenzo Teso ${ }^{1, *}$, Laura Carnieletto ${ }^{2}$, Angelo Zarrella ${ }^{2}$ and Piercarlo Romagnoni ${ }^{1}$ \\ 1 Department of Architecture and Arts, University IUAV of Venice, Dorsoduro 2206, 30123 Venezia, Italy; \\ tdallamora@iuav.it (T.D.M.); pierca@iuav.it (P.R.) \\ 2 Department of Industrial Engineering-Applied Physics Section, University of Padova, Via Venezia 1, \\ 35131 Padova, Italy; laura.carnieletto@unipd.it (L.C.); angelo.zarrella@unipd.it (A.Z.) \\ * Correspondence: 1teso@iuav.it
}

check for

updates

Citation: Dalla Mora, T.; Teso, L.;

Carnieletto, L.; Zarrella, A.;

Romagnoni, P. Comparative Analysis

between Dynamic and

Quasi-Steady-State Methods at an

Urban Scale on a Social-Housing

District in Venice. Energies 2021, 14,

5164. https://doi.org/10.3390/

en14165164

Academic Editor: Patrick Phelan

Received: 15 July 2021

Accepted: 19 August 2021

Published: 20 August 2021

Publisher's Note: MDPI stays neutral with regard to jurisdictional claims in published maps and institutional affiliations.

\section{Copyright: (C) 2021 by the authors.} Licensee MDPI, Basel, Switzerland. This article is an open access article distributed under the terms and conditions of the Creative Commons Attribution (CC BY) license (https:/ / creativecommons.org/licenses/by/ $4.0 /)$.

\begin{abstract}
The residential building stock represents one of the major players in energy use and greenhouse gas emissions; thus, it is fundamental to reduce the energy used. Simulation tools are becoming more and more accurate in compliance with the new requirements both at the singlebuilding and at the district scale, although they are not affordable by non-specialist users such as policymakers. The research concerns the evaluation of the energy demand for space heating for a historical district that is representative of the Italian building stock. The work compares dynamic and specialist-oriented urban scale tools such as Energy Urban Resistance Capacitance Approach (EUReCA) and City Energy Analyst (CEA)) as well as a quasi-steady-state calculation method (Excel spreadsheet), which is more affordable for non-specialist users. The work was carried out to assess the possible deviation of the results between the dynamic and quasi-steady-state calculation methods, as well as to identify any limits and opportunities in the application of the latter procedure, which is currently the official national calculation tool for the implementation of Directive 2010/31/EU. The study shows how the quasi-steady-state method predicts a reliable building energy demand, in line with the results obtained by the two dynamic tools, when considering only geometry and infiltrations as input. However, the limits of the quasi-steady-state method emerge when introducing internal loads, significantly underestimating the energy demand compared to CEA and EUReCA simulations. The results underline the potential application of the quasi-steady-state method to predict energy demand, although dynamics tools are more reliable but far more complex. Major findings through two methods concern the impact of solar heat gains on the overall heating demand at both the single building and the district scale. The different results between the tools provided evidence of a gap in the use of the simplest tool and demonstrated the accuracy and reliability of the proposed approach with a lower computational effort.
\end{abstract}

Keywords: City Energy Analyst; EUReCA; Excel spreadsheet; residential buildings; building energy demand

\section{Introduction}

The building sector is responsible for the highest impact on the environment, mostly because of space heating and domestic hot water (DHW) production [1]. It is known that $30 \%$ of greenhouse gas (GHG) emissions and $40 \%$ of the global energy consumption are due to the building sector [2].

The European building stock is dominated mainly by residential buildings, representing about $75 \%$ of the total floor area. They consume more than $27 \%$ of the total final energy consumed in the European Union [3,4]. When looking at the age of the building stock, almost $67 \%$ of the constructions were built before 1990; thus, the technologies applied are currently at the end of their service life and intervention of building renovation is asupable [5-7]. 
The residential sector covers $80 \%$ of the Italian building stock, and the energy consumed by this sector is about $28 \%$ of the total [8-10]. Analyzing the data from the Italian National Institute of Statistics (ISTAT), it emerges that $86 \%$ of the residential buildings were constructed before 1990, suggesting an even more urgent need for renovations [11,12]. In the last decades, actions to improve energy efficiency in buildings have been promoted through various policies both at national and international scale through directives and laws setting ambitious goals regarding the reduction of GHG emissions and energy use.

Following the indication given by the European Union (EU), many efforts to reduce energy consumption are focused on residential buildings [13]. The literature on the subject is vast and heterogeneous, including best practices to achieve an optimal renovation with the lowest costs. These studies focus on multiple categories of residential buildings (e.g., detached houses, apartment blocks, terraced houses) belonging to different ages ranging from ancient buildings to contemporary constructions. In the last few years, the district-scale approach has become more and more attractive to plan retrofit actions with wider perspectives, working with policymakers and similar professionals. The European Commission (EC) supports several projects applied at the district scale, supporting the idea that this approach can lead to higher savings than the single-building-scale interventions, especially in terms of preliminary energy analysis, design, and construction. Furthermore, the integration of renewable energy sources (RES) may be easier on a larger scale and work more effectively compared to systems that provide heating, cooling, and electricity at the single-building level. Moreover, financial solutions to support the interventions will be more cost-effective and easy to find [14].

The development of computer tools and software for the dynamic energy simulation of buildings experienced an increase in the last few years, following an intensification of research focusing on analyzing the performance and behaviour of structures based on their retrofit. Literature concerning tools for dynamic simulations is already extensive, and various manuscripts deal with comparing the existing software [15-18]. In particular, two recent studies by Zakula, Connolly et al. $[19,20]$ concluded that among all the tools analyzed, none of them was capable of investigating all the aspects related to the performance of building systems and their enhancement. Moreover, RES integration in the renovation process was explored in-depth, underlining the absence of an appropriate tool capable of dealing with this topic $[19,20]$. Although there is a lack of a comprehensive tool for dynamic energy analysis of buildings, some softwares are commonly used in the academic world to deal with these issues. Energy consumption simulation is very critical and TRNSYS [21] and Energy Plus [21-24] are the most used tools for both residential and commercial uses. Other examples of widely used software are Trace 700 and eQUEST $[25,26]$. The main reasons behind their success are the possibility of analyzing in detail the characteristics of energy and technological systems of buildings and simulating the dynamics of structures.

Even though offering numerous advantages, such as accuracy in modeling, flexibility in usage, and detailed results, some disadvantages prevent the widespread use of these tools. The software for building simulation, especially those mentioned before, requires a high level of expertise in the user. A lot of input parameters are usually needed in the process of modeling and characterizing the case study. Moreover, both the modeling and simulation process can be time-intensive, especially when running simulations of large complexes or when a high degree of detail is needed. These disadvantages are an obstacle to the widespread use of this software, especially for people who lack the know-how, specific skills, or time to carry out such long and complex analyses [17].

Moreover, quasi-steady-state tools could be considered to determine energy models and simulations for buildings, especially at the beginnings of the design process to help planners understand the relationship between the energy need, built form, and energy opportunities for buildings and the neighborhood.

In a steady-state regime, variables such as solar radiation or air temperatures are fixed over time, while boundary condition data such as climate variables are time integrated 
using seasonal or monthly average values (consumption calculation methods) or peak values (for HVAC system sizing) [17].

This approach will usually tend to overestimate the operating hours or to oversize the plant capacity because the peak power demand is considered for pre-feasibility studies and only yearly-monthly consumption data are assumed for business plans [27].

Moreover, in such building energy simulations, it is common practice to evaluate power demand by using at least the hourly energy demand. However, the power demand simulation in the context of buildings is more sophisticated at the urban scale for different reasons [28]. Firstly, it is necessary to have a vast amount of data about built construction and components (geometrical information, thermo-physical properties, etc.), and the urban environment of each building has to be considered in terms of point, meteorological loads depending on obstructions, surrounding surfaces, and urban morphology. Moreover, the diversity of occupant behaviour, direct actions and use of heating, ventilation, and air conditioning (HVAC) systems at the urban scale influences the spatio-temporal patterns of energy demand [29]. One key limitation of steady-state models consists of the rather simplified behavior of building occupants. The effects of occupants on district scale energy demand needs an improved analysis because their activities are responsible for the energy need in the considered area [30]. Then, the max power demands of a district are not the same as the sum of the max power demands of each building [31].

Many companies, including energy saving companies (ESCos), software houses, and research institutions have developed several tools for dynamic energy simulation of buildings in past years. In many cases, these tools focus on the simulation of individual units or small groups of buildings [32]. However, there are also tools developed to study the dynamics of city districts and various configurations of retrofit interventions on buildings to enlarge the study up to hundreds of buildings. For this reason, various models and tools have been developed specifically for assessing building energy supply and demand at the urban level [32-34].

Concerning energy models at the district and city scale, some tools have been developed so far with the steady-state approach, focusing on policy makers as type of user, thus falling into f Feasibility Model or Planning tool category. The spreadsheet tool Plan4DE [35] by IEA DHC or the EU-funded project ExcEED [36] or the Open source Hotmaps [37] or Thermos [38] are some examples.

This paper aims to increase the level of knowledge surrounding the two methodologies for building simulation (i.e., dynamic and quasi-steady-state), employing a comparison to highlight the limitations and the advantages of both approaches. The aim of this work is the estimation of the forecasts of energy use and consumption in residential buildings representative of the Italian building stock via dynamic and quasi-steady-state calculation methods, in order to assess the possible deviation of results between them, as well as identifying possible limits and opportunities in the application of the most straightforward procedure, the quasi-steady-state. In particular, the application of the quasi-steady-state calculation method could be used by non-specialist users, for instance urban planner or politicians, to determine the energy needs of a district of buildings or individual constructions. In this case, no previous deep knowledge in urban simulation is necessary, and filling a spreadsheet is sufficient to have a global understanding of the energy functioning of the district.

Even though each tool can estimate space heating and cooling energy demand as well as domestic hot water needs, the paper focused on the space heating demand as it is responsible for the highest energy use.

\section{Materials and Methods}

The analysis was performed by comparing the quasi-steady-state simulation, conducted using the MS Excel worksheet with the software City Energy Analyst (CEA) [39,40], developed by the ETH Zurich, and focused on the energy simulation of city districts. The buildings used as a case study for the research are a series of residential buildings located in 
the city of Venice, Italy. A further comparison will be developed with the tool EUReCA (Energy Urban Resistance Capacitance Approach) [41-43] based on the resistance-capacitance approach suggested by the EN ISO 13790:2008 Standard [44]. They represent the type of multi-family building built between the two world wars to cope with the enormous emigration of people who moved from the countryside to the cities searching for work.

\subsection{Dynamic State Simulation by City Energy Analyst Simulation Tool}

For the research conducted and described in this manuscript, it has been decided to use City Energy Analyst (CEA). CEA is an open-source tool developed by the Architecture and Building Systems (A/S) Group of the ETH Zurich, which allows analysis and optimization for energy systems in city districts, energy modeling of building datasets, development of retrofit strategies at the district level, urban planning, $\mathrm{CO}_{2}$ emissions, and economic benefits for retrofit strategies. Moreover, it enables professionals to plan district energy systems and assess the possible exploitation of on-site renewables $[45,46]$.

The software, developed using Python programming language in its 2.7 version, is built as an extension of ArcGIS version 10.3. CEA's framework for energy analysis employs seven databases and six calculation modules. For our research, the most important databases are weather, urban, and archetypes. The weather database contains historical data related to atmospheric characteristics such as temperature, relative humidity, and solar radiation of the place of interest. The urban database comprises geo-referenced info related to the buildings, infrastructure, and topography of the site. Building characteristics are considered such as height, WWR - window to wall ratios, footprint area, type of use, date of construction, and last renovation. The archetypes database is used to describe envelope and HVAC characteristics for building stock. It is based on statistical data, but actual data from other sources can be used. For the calculation modules, formulas developed within the research of the A/S group are used [45]. These modules are designed to simulate resource availability potential, optimization, and visualization of building energy systems, moving from the individual building scale to the district scale. For this, a simplified supply chain including all energy flows in the generation, conversion, distribution, emission, and transfer subsystems at the district level is taken into account. Formulas based on EN ISO 13790:2008 Standard are used for the dynamic calculation of the building energy demand. In the model, the final energy demand is split into the main uses and estimated on an hourly basis [46].

\subsection{Dynamic State Simulation by EUReCA}

A new Python-based tool, EUReCA, recently presented by Prataviera et al. [42], has been applied to the case study. The EUReCA platform implements a 5R1C model described in the EN ISO 13790:2008 Standard, managing both GeoJSON and CityJSON data to define the buildings' geometry. The tool is a bottom-up simulation software for predicting hourly heating and cooling energy demand and consumption applied to large districts and cities.

Several urban building energy modeling (UBEM) tools use geo-referenced semantic models to describe cities' buildings, roads, vegetation, and infrastructure to represent cities' geometries, properties, and attributes in 3D. In particular, EUReCA can handle CityJSON models that correspond to 3D and 2D GeoJSON models derived from ESRI Shapefiles by recreating the geometry of building context, thus allowing the representation of cities that are not already available with 3D georeferenced models and increasing the flexibility of these tools. Although the loading process of the geometric input is slightly different between CityJSON and GeoJSON files, they allow the creation of the building object after the initialization of the building's surfaces and the correlation with end-use and age-class. The management of the input data handled by the building class creates the thermal zone and the related network parameters, as described in the calculation scheme by Prataviera et al. [42]. Even though the detailed thermal zone model applied in singlebuilding modeling results in accurate estimations of the thermal performance of buildings, the high level of detailed information and the related computational effort for the input 
elaboration highlight the need for simplified thermal zone models for urban scenarios. EUReCA calculates thermal losses (transmission and ventilation) and building thermal inertia through an equivalent electrical network that combines all building structures into five thermal resistances and one thermal capacitance, as described in Figure 1.

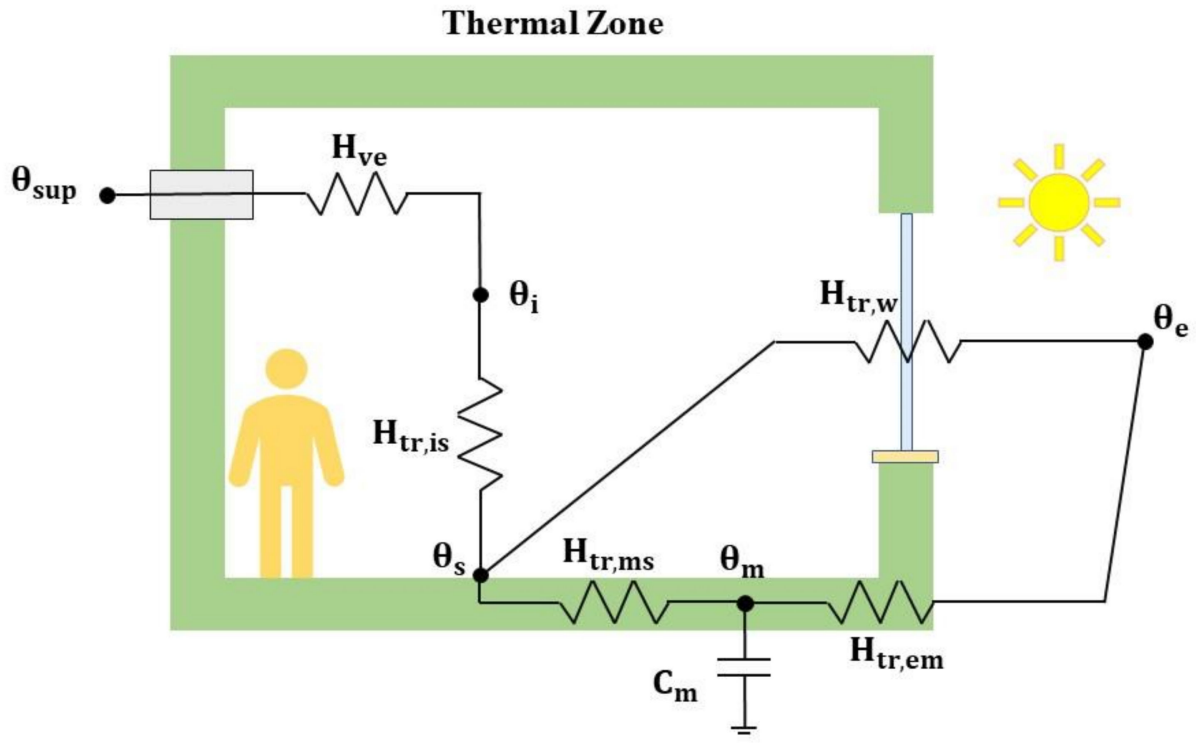

Figure 1. 5R1C thermal network scheme [47].

A simple thermal zone can be modeled by three thermal nodes (internal air $i$, all surfaces $s$, all structures mass $m$ ) and two boundary condition nodes (supply air sup and external air $e$ ). The five thermal heat transfer coefficients are: the ventilation heat transfer coefficient $\mathrm{H}_{\mathrm{ve}}$, the glazed surfaces transmission coefficient $\mathrm{H}_{\mathrm{tr} ; \mathrm{w}}$, the coupling conductance between node $m$ and node $e \mathrm{H}_{\text {trem }}$, the coupling conductance between node $s$ and node $m$ $\mathrm{H}_{\text {tr;ms }}$ (which gives the opaque structures heat transfer coefficient $\mathrm{H}_{\text {tr;op }}$ in combination with the previous $\mathrm{H}_{\text {tr;em }}$ ), and the coupling conductance between node $i$ and node $s \mathrm{H}_{\text {tris }}$.

Standard UNI EN ISO 13786 is adopted to calculate the thermal capacitance $\mathrm{Cm}$ (including the thermal inertia of all thermal zones). Solar and internal heat gains are split into three components, each one connected to a network's node. A linear system of three equations and four unknown terms is obtained by writing the thermal balance at each thermal node, which can be solved by setting the heat flux (calculating the air temperature) or the internal air temperature (calculating the heat flux) [47]. The simulation is run for each district's building at each timestep set by the user. The boundary conditions refer to an .epw weather data file [48].

\subsection{Quasi-Steady-State Simulation by Spreadsheet Tool}

The primary energy demand evaluation for building heating and cooling has been developed by the quasi-steady-state method as defined in standard UNI TS 11300 [49].

A tool developed for previous research [50,51] has been implemented with technical specifications and consists of user-friendly MS Excel spreadsheets, providing the monthly energy consumption for heating, cooling, and DHW production for each considered building.

The tool is composed of several calculation sections. The first part consists of input data such as conversion factor, weather data, building geometric data, and thermal transmittance of the opaque and glazing envelope. In contrast, the second section reports the main results in terms of space heating and cooling energy demand, primary energy demand, and use and power peak.

Datasets about price, emission, and primary energy conversion factors hold the specific data according to national standards [52] or statistical databases [2]. 
Weather data refer to the Italian Thermomechanical Committee CTI [53] database that provides the hourly values for each reference station, referring to the characteristic meteorological year calculated according to standard UNI EN ISO 15927-4 [54].

The tool also supports conventional climatic data as in UNI 10349-1:2016: this national standard comprehends monthly average data (temperature of air, global radiation, direct and diffuse solar irradiation, wind speed, water vapour pressure) developed on reference years for main Italian locations [55].

The heating period is determined according to the climatic zone and the local heating degree days (HDD), as stated by the D.P.R. 412/93 [56] and the D.P.R. 74/2013 [57].

In particular, the evaluation by quasi-steady-state model assumes and calculates, for each location, monthly average values of air temperature in the building neighbourhood, incident solar radiation for each orientation and on the horizontal plane, and temperature of the celestial vault.

Building geometrical data are calculated according to values of building footprint area, level gross height, number of levels, and number of dwellings for each level. For example, the windows' surface could be filled by survey data or assumed as a percentage value related to the heated floor area.

For the calculation of the heating demand, the UNI/TS 11300-1:2014 standard was adopted, by applying the following formula (Equation (1)) [58]:

$$
Q_{H, n d}=\left(Q_{H, t r}+Q_{H, v e}\right)-\eta_{H, g}\left(Q_{i n t}+Q_{s o l}\right)[k W h]
$$

where

$Q_{H, n d}$ : total energy exchange for space heating;

$Q_{H, t r}$ : heat losses through transmission;

$Q_{H, v e}:$ heat losses through ventilation;

$Q_{\text {int }}$ : internal heat gains;

$Q_{\text {sol }}$ : solar heat gains;

$\eta_{H, g}$ : factor for heat gains.

The thermal characteristics of opaque and glazing envelope components in the building are described simplified by values of thermal transmittance (intended not to include thermal bridges) and solar energy transmittance of glazed (Equation (2)):

$$
Q_{H, t r}=0.024 \cdot\left(\sum_{i} b_{t r} U_{i} A_{i}\right) \cdot\left(T_{i n t}-T_{\text {ext }}\right) \cdot \tau+Q_{t r, i r}[k W h]
$$

where

$U_{i}$ : thermal transmittance of the $i$ th surface composing the thermal envelope $\left(\mathrm{W} / \mathrm{m}^{2} \mathrm{~K}\right)$;

$A_{i}$ : area of the $i$ th surface composing the thermal envelope $\left(\mathrm{m}^{2}\right)$;

$b_{t r, i}$ : correction coefficient for heat transfer depending on the type the $i$ th surface. For ground, cellar, and nonadiabatic shared surfaces, it yields 0.5 and for adiabatic shared surfaces- 0 , for glazed surfaces- 1 , otherwise -1.05 ;

$t_{\text {int }}$ : internal room temperature, fixed at $21^{\circ} \mathrm{C}(\mathrm{K})$;

$t_{\text {ext }}$ : monthly average external temperature $(\mathrm{K})$;

$\tau$ : length of the heating period for each month, in days;

0.024: dimensional conversion factor;

$Q_{t r, i r}$ : heat losses due to radiation, computed as in ISO 13790:2008, in (kWh).

Heat losses through ventilation (Equation (3)) are fixed according to an air exchange rate set at $0.5 \mathrm{~h}^{-1}$, consistently with the assumptions of the simplified method in UNI/TS 11300-1. In the unheated zones, a constant hourly change of $0.5 \mathrm{~h}^{-1}$ is assumed.

$$
Q_{H, v e}=6.67 \cdot 10^{-3} \cdot c \rho_{\text {air }} n_{v e} V_{\text {heated }}\left(t_{\text {int }}-t_{\text {ext }}\right) \cdot \tau[k W h]
$$

where

$c p_{\text {air }}:$ volumetric heat capacity of air fixed at $1.2 \mathrm{~kJ} /\left(\mathrm{m}^{3} \mathrm{~K}\right)$; 
$n_{v e}$ : air exchange rate, fixed at $0.5 \mathrm{~h}^{-1}$;

$V_{\text {heated }}$ : heated volume $\left(\mathrm{m}^{3}\right)$;

$t_{\text {int }}$ : internal zone temperature fixed at $21^{\circ} \mathrm{C}(\mathrm{K})$;

$t_{\text {ext }}$ : monthly average external temperature $(\mathrm{K})$;

$\tau$ : length of heating period for each month, in days;

$6.67 \cdot 10^{-3}$ : dimensional conversion factor.

Internal heat gains are computed according to an average value $\left(4 \mathrm{~W} / \mathrm{m}^{2}\right)$ for heated floor area, including gains due to occupants and equipment. This value could be split according to the building typology: $2.58 \mathrm{~W} / \mathrm{m}^{2}$ for single-family houses or $5.57 \mathrm{~W} / \mathrm{m}^{2}$ for apartment blocks or multi-family houses.

The internal contributions are calculated referring to the average floor area for each accommodation, as per the following formula (Equation (4)):

$$
Q_{\text {int }}=\left\{\begin{array}{cc}
0.024 \cdot\left(5.294-0.01557 A_{f} / n_{f s}\right) A_{f} \cdot \tau, & \text { when } A_{f}<170 \\
0.024 \cdot 4 A_{f} \cdot \tau, & \text { when } A_{f}>170
\end{array}[\mathrm{kWh}]\right.
$$

where

$A_{f}$ : net floor area $\left(\mathrm{m}^{2}\right)$;

$n_{f s}:$ number of full storeys;

$\tau$ : as previously defined;

0.024: dimensional conversion factor.

Solar heat gains are computed according to seasonal average monthly global solar radiation and fixed values such as 0.9 for correction factor due to shadowing from adjacent objects; 0.6 for solar absorption factor; $0.04 \mathrm{~m}^{2} \mathrm{~K} / \mathrm{W}$ surface thermal resistance; and 0.2 for reduction factor for the window frame. In addition, the walls' area, thermal transmittance, and solar energy transmittance for opaque and glazed surfaces are computed for each orientation.

Finally, the utilization factor for heat gains $\left(\eta_{H, g}\right)$ is determined according to EN ISO 13790:2008, assuming $\mathrm{a}_{\mathrm{H}, 0}=1$ and $\mathrm{t}_{\mathrm{H}, 0}=15 \mathrm{~h}$.

The subsystems' efficiencies (emission, control, distribution, production) are defined based on the types of systems adopted through the pre-calculated values reported in the technical specification.

The heating system is simulated with continuous operation at a $20^{\circ} \mathrm{C}$ setpoint for the whole week during the heating period, regardless of the periods of occupation of the building. The same setting is fixed for the cooling period, with setpoint equal to $26^{\circ} \mathrm{C}$.

The results are reported in terms of useful thermal energy for heating $\left(Q_{H, n d}\right)$ and cooling $\left(Q_{\mathrm{C}, n d}\right)$ and in terms of global primary energy for heating $\left(\mathrm{E}_{\mathrm{P}, \mathrm{H}}\right)$, cooling $\left(\mathrm{E}_{\mathrm{P}, \mathrm{C}}\right)$, and for domestic hot water $\left(\mathrm{E}_{\mathrm{P}, \mathrm{W}}\right)$ normalized on the heated floor area.

\section{Case Study}

The research aims to highlight the differences in using three software for energy simulation at the district level. An existing case study was selected and studied with a quasi-steady-state method and two dynamic simulation tools for urban scale simulations, estimating the energy consumption of buildings.

Since almost $26 \%$ of the Italian stock was built before 1945 [8], the case study has been selected to be representative of the Italian situation of historical city centers, mostly focused on multi-storey residential buildings belonging to the period between the two world wars. For these reasons, the selected district is the residential district of Santa Marta in Venice. The district was chosen considering the potential nationwide replicability. In the city of Venice, several districts similar to Santa Marta were built between 1910 and 1950, for a total of about 3000 accommodations. Immediately after the World Wars, the lack of housing units due to the devastation and immigration of people from the countryside to the industrial cities led to the need for a huge housing capacity in a short time. Therefore, several architectural typologies belonging to that historical period were later replicated 
throughout the city and the whole nation. The institute that has been involved from the very beginning in the construction and management of these complexes, ICP-Istituto Case Popolari (Public Housing Institute), was a national agency diffuse in all major Italian cities. For this reason, the high replicability of this case study can have national soundness for the retrofit of social housing neighborhoods [59-61].

The full name of the district is "Santa Marta ICP housing", and it is located in the west part of Venice in the Dorsoduro district (Figure 2). It was built starting in 1920 when the city administration began the construction of 14 buildings for a number of apartments close to 150 units for people with low income and workers of the nearby cotton mill. In 1930, the district was expanded with a second intervention to construct 365 new apartments distributed in 21 buildings [62]. Although the shape is irregular, the size of the neighborhood is about $400 \mathrm{~m}$ by $150 \mathrm{~m}$ for an area of about $0.05 \mathrm{~km}^{2}$.
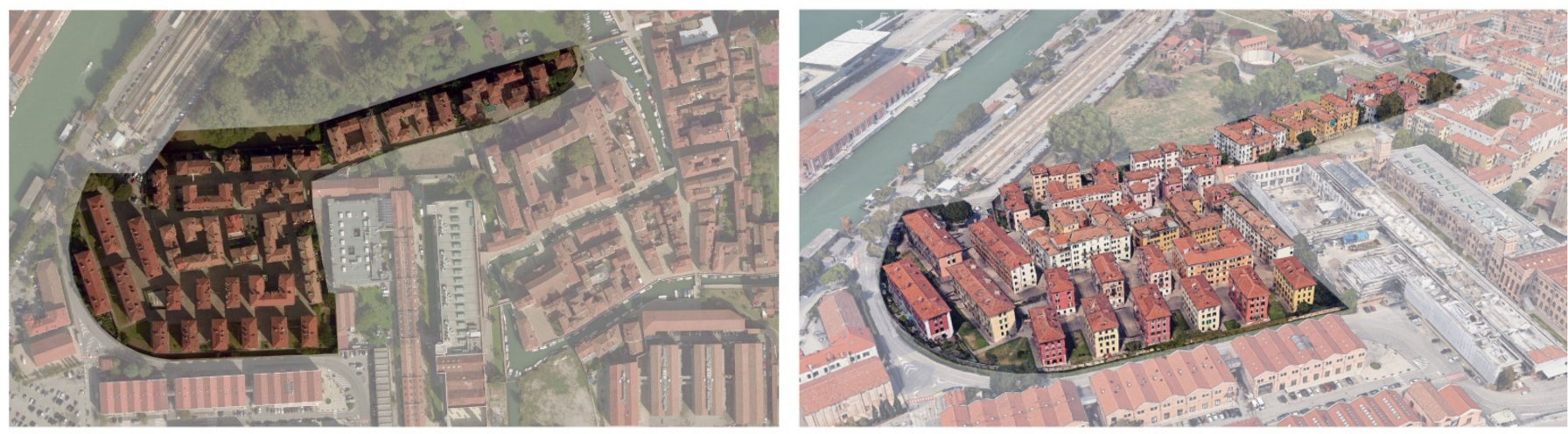

Figure 2. Satellite view and 3D visualization of Santa Marta district in Venice.

The district is mainly composed of multi-family, multi-story buildings, and only four buildings can be classified as mixed-use due to the presence of retail spaces or restaurants on the ground floor. Depending on the construction period, buildings can be divided into two groups that differ in the geometry of the building. The first group of multi-family houses was built between 1920 and 1928 and had a regular rectangular footprint with a constant size for the short side of $12.5 \mathrm{~m}$, while the length of the long side varies between the different buildings with values between 20 and $50 \mathrm{~m}$. All the buildings in this group have four floors and a number of apartments per floor, varying between two and six depending on the size of the building.

The second group was built between 1930 and 1936. The geometries are more complex and variable but traceable to the building typology of courtyard or " $\mathrm{C}$ "-shaped building, with footprints ranging between 150 and $1500 \mathrm{~m}^{2}$. There is no harmony even concerning the number of floors per building: two-story buildings are merged with buildings up to five floors. These differences are also reflected in the number of apartments ranging from buildings with one home unit per floor to buildings with as many as fifteen per floor.

The homes considered in the case study were built to end the precarious living conditions of the lower classes and thus had to be low cost, but they must comply with the latest health and hygiene regulations. For this reason, constructions must be simple and easy to build. For both groups defined above, the same technologies were used. As described in Table 1, the external walls are made of brick masonry without insulation as well as plaster on both the internal and external sides. The sloping roof is built with a wooden frame without insulation and clay tiles on the external side, while the ground floor consists of a non-insulated slab cast on a rock foundation and ceramic tiles on the inside. Originally, all buildings had single glass windows with wooden frames, but some were recently replaced by double glass windows with wooden frames. The space heating system is a centralized gas boiler installed in each building, which distributes hot water through uninsulated pipes to cast iron radiators in the rooms. The overall efficiency of these kinds of system is $80 \%$. Domestic hot water is supplied by electric or gas-fired water heaters 
installed in each apartment with an efficiency equal to $80 \%$. There is no centralized cooling system, but tenants installed air conditioners over the years in some cases.

Table 1. Thermal transmittance and components of the envelope elements.

\begin{tabular}{|c|c|c|}
\hline Element & $\begin{array}{l}\text { Components } \\
\text { from Exterior to Interior }\end{array}$ & Thermal Transmittance $\left[\mathrm{W} /\left(\mathrm{m}^{2} \mathrm{~K}\right)\right]$ \\
\hline External wall & $\begin{array}{l}\text { External plaster }(1.5 \mathrm{~cm}) \\
\text { Solid bricks }(25 \mathrm{~cm}) \\
\text { Internal plaster }(1.5 \mathrm{~cm})\end{array}$ & 1.35 \\
\hline Floor slab & $\begin{array}{l}\text { Screed }(30 \mathrm{~cm}) \\
\text { Concrete casting }(10 \mathrm{~cm}) \\
\text { Traditional screed }(3 \mathrm{~cm}) \\
\text { Stoneware floor }(1.5 \mathrm{~cm})\end{array}$ & 1.41 \\
\hline Roof & $\begin{array}{l}\text { Terracotta tiles }(1.2 \mathrm{~cm}) \\
\text { Wood panel }(3 \mathrm{~cm})\end{array}$ & 2.5 \\
\hline Single-glazed windows & $\begin{array}{l}\text { Wood frame } \\
\text { Single glazing }\end{array}$ & 5.8 \\
\hline
\end{tabular}

\section{Computer Simulations}

The test analyzes the residential district of Santa Marta in Venice with the aim to calculate and compare the heating needs using two different calculation methods and three different models: quasi-steady-state monthly-based using an MS Excel spreadsheet and dynamic on an hourly basis using CEA and EUReCA.

The tools used were set with the same input data such as climate information, building geometry, thermo-physical characteristics of the building envelope, efficiency values and capacity of the plant system, activity-use, and population density of the buildings that have been described in the previous paragraphs.

Further clarifications regarding the calculation settings will be presented.

\subsection{Weather Data}

The climatic data used for both tools are extracted from the EnergyPlus weather file of the Venice Tessera station in order to make a comparison using the same source $[48,63]$.

The .epw data for the Italian cities refer to two sources: the International Weather for Energy Calculation (IWEC), typical weather files (c) 2021 ASHRAE, and the Italian Climatic data collection "Gianni De Giorgio" (IGDG), based on recorded data from the period between 1951 and 1970 [64].

According to Italian standards, Venice is located in climate zone E, having $2345 \mathrm{HDD}$. This value comes from DPR 412/1993, a law containing for all major Italian localities the corresponding value for HDD [56], based on the European standard EN ISO 15927-6 2007 that specifies the definition, method of calculation, and presentation of data used to estimate the energy used for heating [65]. Based on this datum, the limits for the use of heating are defined: from October 15th to April 15th for a maximum of $14 \mathrm{~h}$ per day [57].

As previously described, the determination of building energy performance can adopt two different official archives: the standard UNI 10349-1:2016, reporting climate monthly average data as used in the steady-state method given in EN ISO 13790:2008, and an archive (such as the Energy Plus Weather archive) of test reference years with hourly values used in dynamic simulation procedures.

As can be seen from the comparison in Table 2, the values related to external temperature and monthly average global irradiation were quite different between the two sources. The .epw files are based on weather reports from the 1970s, whereas the UNI 10349 standard has been revised using weather measurements made in more recent years; therefore, the spreadsheet tool handles the monthly average values obtained by the climatic file epw. 
Table 2. Weather data comparison.

\begin{tabular}{|c|c|c|c|c|}
\hline \multirow[b]{2}{*}{ Month $\backslash$ Source } & \multicolumn{2}{|c|}{$\begin{array}{c}\text { Dry Bulb Temp-Avg Daily } \\
{\left[{ }^{\circ} \mathrm{C}\right]}\end{array}$} & \multicolumn{2}{|c|}{$\begin{array}{c}\text { Global Horiz Radiation-Avg Daily } \\
{\left[\mathrm{kWh} / \mathrm{m}^{2}\right]}\end{array}$} \\
\hline & Venice.epw & UNI 10349-1:2016 & Venice.epw & UNI 10349-1:2016 \\
\hline January & 2.64 & 3.10 & 0.88 & 1.25 \\
\hline February & 3.89 & 3.70 & 1.15 & 2.25 \\
\hline March & 7.75 & 8.70 & 2.56 & 3.47 \\
\hline April & 12.03 & 12.90 & 3.71 & 4.69 \\
\hline May & 17.24 & 19.00 & 5.02 & 6.08 \\
\hline June & 20.76 & 22.40 & 5.47 & 7.17 \\
\hline July & 23.82 & 23.80 & 5.68 & 7.53 \\
\hline August & 22.75 & 23.80 & 4.68 & 6.14 \\
\hline September & 19.62 & 18.70 & 3.35 & 4.39 \\
\hline October & 13.93 & 14.00 & 1.96 & 2.72 \\
\hline November & 8.68 & 8.40 & 0.91 & 1.47 \\
\hline December & 4.00 & 4.90 & 0.73 & 1.14 \\
\hline
\end{tabular}

\subsection{Geometry}

The geometry of the buildings is based on the data reported in the regional cadastral archives and on the measurements carried out in the geometric survey.

For this purpose, a cadastral database has been used, precisely the online Catalog of Territorial Data by the Veneto Region, and subsequently modified and converted into shape format (.shp and .shx) in order to be accessible from CEA.

The geometric changes made concern the heights and the footprint of the buildings. In the cadastral register, the map shapes consist of different structures and therefore have different heights. Thus, the modification consists of dividing the maps (or cadastral cells) into smaller ones with homogeneous heights.

The buildings analyzed represent the current real situation and are characterized by regular and homogeneous volumes and have been classified by map number and homogenous height, obtaining 52 buildings (Figure 3).

However, a discrepancy is noted in the reading and association of cadastral data by CEA: the footprint values used by CEA are different, or rather discretized, according to the segments that make up the boundary of the footprint. In this case study, the total area of the district is the same both in CEA and cadastral; however, the differences at single building scale have some consequences in the processing of parameters to obtain the floor area, the heated useful area, the volume and the exposed surfaces, both opaque walls, and the window fraction. In particular, the overall area processed by CEA is only $1 \%$ smaller than the cadastral data.

The same inputs must be defined to compare the tools; therefore, in CEA, a value equal to 0.8845 was applied as ratio between net area and gross area. This value corresponds in the spreadsheet to the application of the formula for the surface Af, based on the thickness of the external walls of about $0.30 \mathrm{~m}$ measured by a survey on site.

In CEA, the geometry modeling takes several steps. Firstly, the definition of the footprints of the buildings using a free and open-source GIS application, such as QGIS in version 3.10.0, allows the user to analyze and modify geospatial data [66] or to import 2D georeferenced maps. Usually, this process is accompanied by the use of a map provider as such as Open Street Map [67] which contains information about the buildings, as each of them is associated with a table that includes various necessary features for the simulation of the model. Unfortunately, this situation does not apply to the case study. As a consequence 
of the lack of exhaustive data collection and unitarity between the various databases, the only information reported in the 2D model is the area and the perimeter of the buildings.

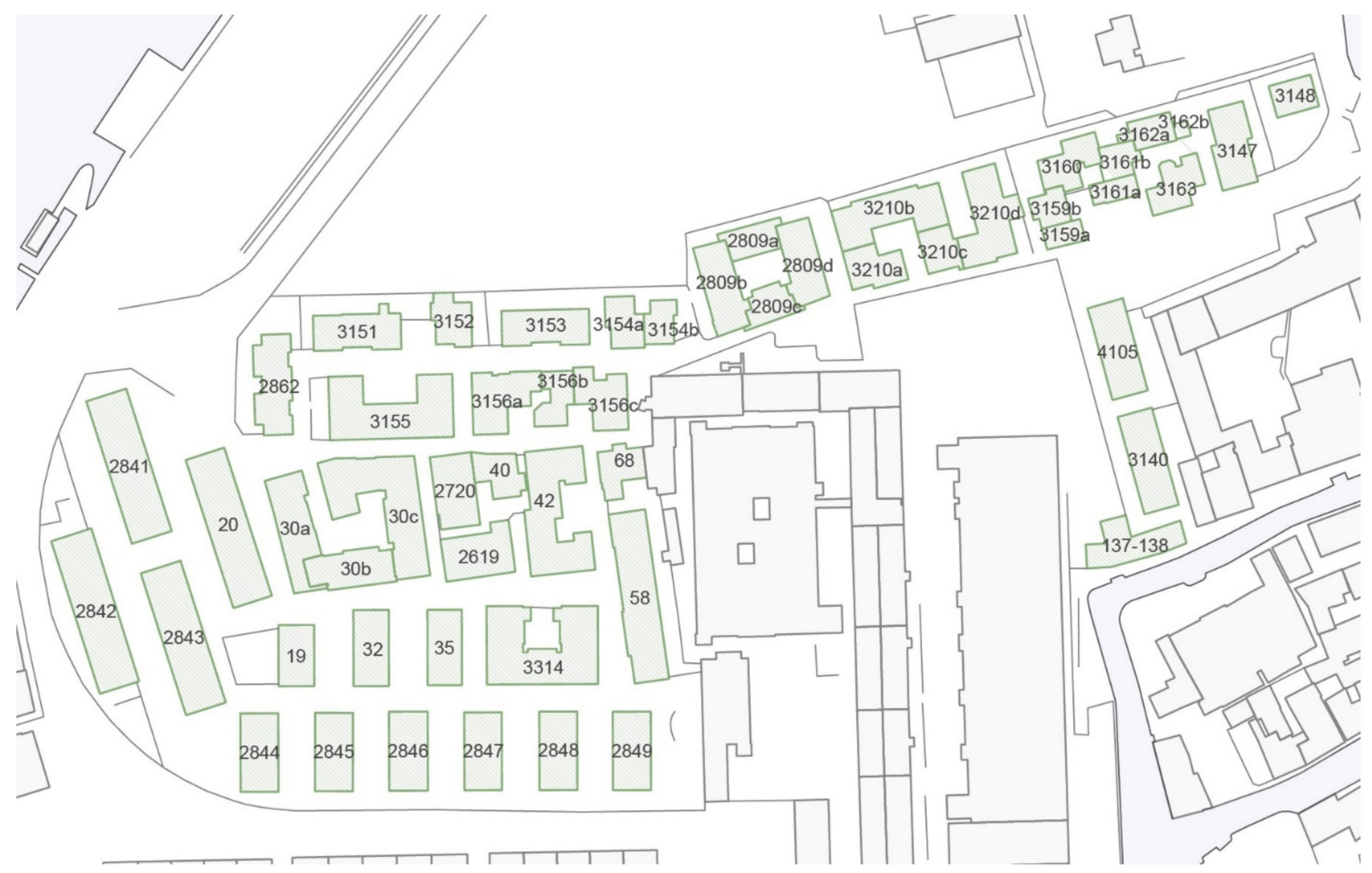

Figure 3. Subdivision and nomenclature of the buildings.

This situation requires to use additional databases that record the data for the missing parameters $[68,69]$. The first source used is the cadastral maps of the Venice municipality through which information about the height of the buildings and the number of floors has been obtained. The cadastral maps also summarize the space end-use that allows a first rough classification of the building type. Following this first definition, data enrichment is necessary to provide more information about the use and number of floors of the building. Using additional cadastral maps and web mapping portals, the data obtained have been validated and further confirmed through the use of online map providers such as Bing Maps or Google Maps [70,71]. The last step is the definition of the age of the buildings. Through various historical maps, it is possible to go back roughly to the years in which the buildings were built, and since there is also a detailed report, it was possible to define the vintage of the buildings [72].

As previously explained, EUReCA handles a GeoJSON file to obtain the geometric information; thus, the same shapefile elaborated by CEA has been used. Even though the input shapefile is the same, the overall area of the district has a $0.7 \%$ overestimation compared to CEA due to internal approximation of the footprint calculation method.

\subsection{Internal Gains}

Reliable reference values concerning internal heat gains representative of typical residential use are given by standard EN 16798 [73]. It defines an occupancy density of $30 \mathrm{~m}^{2}$ / person for multi-family residential buildings similar to the case study, corresponding to about four people per apartment. Given the age of the buildings and the few retrofits made over the years, air infiltration is set constantly at 0.5 air changes per hour [73]. 
According to the UNI/TS 11300-1 standard, the value of $4 \mathrm{~W} / \mathrm{m}^{2}$ has been used both for household appliances and lighting points, considering that the tenants are people with economic issues [49]. In the dynamic tools, internal loads have been applied according to the schedules reported in Figure 4.

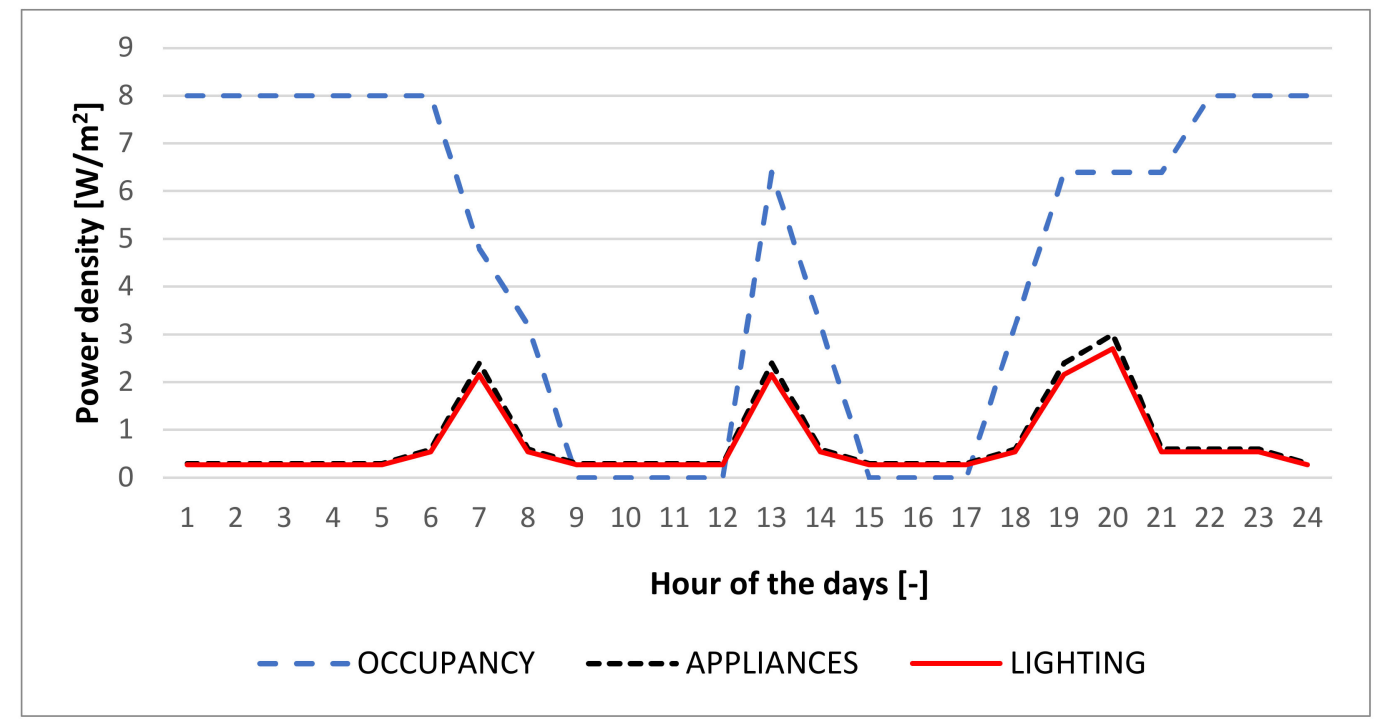

Figure 4. Internal heat load density profile of the residential building during a week.

In general, internal gains have been evaluated according to the actual users and to the survey data. Elderly people predominantly inhabit the Santa Marta district, so the adopted schedule refers to a user-kind that spends most of time at home and to a continuous use during the week, without differences between weekdays and weekends. Appliances and lighting present a similar schedule because the reference value is the same according to UNI/TS 11300-1 Standard $\left(4 \mathrm{~W} / \mathrm{m}^{2}\right)$, and the schedule adopted refers to survey data and presents the same trend.

\subsection{Solar Gains}

Solar heat gains can strongly affect the heating-cooling load, especially with lowperformance glazed components; therefore, a detailed evaluation of solar heat gains has been developed. The calculation of the solar gains implemented with the quasi-steady-state method is based only on the glazed surfaces using a seasonal average value of incident solar radiation for each orientation, but it does not consider the mutual shading of the buildings.

The values considered in the spreadsheet model are the climatic data for the location of Venice extracted from the climatic file .epw, considering precisely the values of daily average monthly solar irradiation (Table 3).

On the contrary, solar gains are estimated in CEA based on the hourly [45] solar radiation incident on the glass surface, which are calculated with the hemispheric viewshed algorithm of Fu et al. [74], implemented in ArcGIS 10.2.1 [75]. The solar heat gains of buildings are calculated by DAYSIM simulation engine [76], integrated in CEA and considers the mutual shading between buildings.

The solar radiation implemented for EUReCA is based on the EN ISO 13790:2008 Standard, further improved with the Lawrence Berkeley National Laboratory (LBNL) model proposed by Arasteh et al. [77]. The model defines angular dependent profiles for reflectance, transmission, and SHGC using U-values and normal incidence Solar Heat Gain Coefficient (SHGC), considering the window as a simplified equivalent layer. 
Table 3. Average daily monthly solar irradiation on a vertical plane for orientation for the winter period.

\begin{tabular}{ccccc}
\hline & South & East & West & North \\
\hline & {$\left[\mathbf{k W h} / \mathbf{m}^{2}\right]$} & {$\left[\mathbf{k W h} / \mathbf{m}^{2}\right]$} & {$\left[\mathbf{k W h} / \mathbf{m}^{2}\right]$} & {$\left[\mathbf{k W h} / \mathbf{m}^{2}\right]$} \\
\hline January & 2.18 & 1.42 & 1.45 & 0.89 \\
\hline February & 2.07 & 1.34 & 1.37 & 0.84 \\
\hline March & 3.15 & 2.05 & 2.09 & 1.29 \\
\hline April & 3.12 & 2.02 & 2.06 & 1.27 \\
\hline October & 3.11 & 2.02 & 2.06 & 1.27 \\
\hline November & 2.08 & 1.35 & 1.38 & 0.85 \\
\hline December & 2.02 & 1.31 & 1.34 & 0.82 \\
\hline Average & 2.43 & 1.58 & 1.61 & 0.99 \\
\hline
\end{tabular}

\section{Results}

Several simulations have been performed to estimate the space heating energy demand obtained with the three tools (quasi-steady-state spreadsheet compared to CEA and EUReCA). In particular, a set of three simulations has been used to evaluate the influence of different inputs on the simulation results:

1. S01-Infiltration rate and internal gains neglected, to consider only the influence of the envelope transmission losses;

2. S02-Evaluation of the infiltration rate set equal to $0.5 \mathrm{~h}^{-1}$;

3. S03-Calculation of the heating energy demand considering both internal heat gains and infiltration.

The results obtained with the different tools have been described in detail in the following paragraphs.

\subsection{Case S01}

When running the first simulation, case S01, with nor internal gains nor infiltration flow rate, the space heating energy demand of buildings is related only to the thermal transmission losses through the envelope.

Figure 5 shows the energy need for space heating at the single-building scale. While CEA and the quasi-steady-state method have a negligible difference, the 5R1C method implemented in EUReCA slightly overestimates the energy required (on average around $10 \%$ compared to CEA and 11\% compared to MS Excel), probably due to the slightly higher external wall area calculated and the different methods applied for the calculation of the solar radiation explained in the previous paragraph.

The internal walls' capacity is calculated equally by CEA and EUReCA, considering the area of internal partitions equal to 2.5 times the internal floor area, as indicated by EN ISO 13790:2008 Standard. However, internal walls have not been included in the MS Excel spreadsheet, thus contributing to the gap between the different results.

In general, using the spreadsheet file and the cadastral data, a simplification of the geometry should be applied when contiguous buildings present different heights or number of floors; therefore, some surfaces will not be considered in the modeling and can influence the final results.

In fact, Figure 6 gives evidence of buildings that present different heights within the same unit and the geometric variability of the vertical wall areas that can influence the thermal transmission losses. 


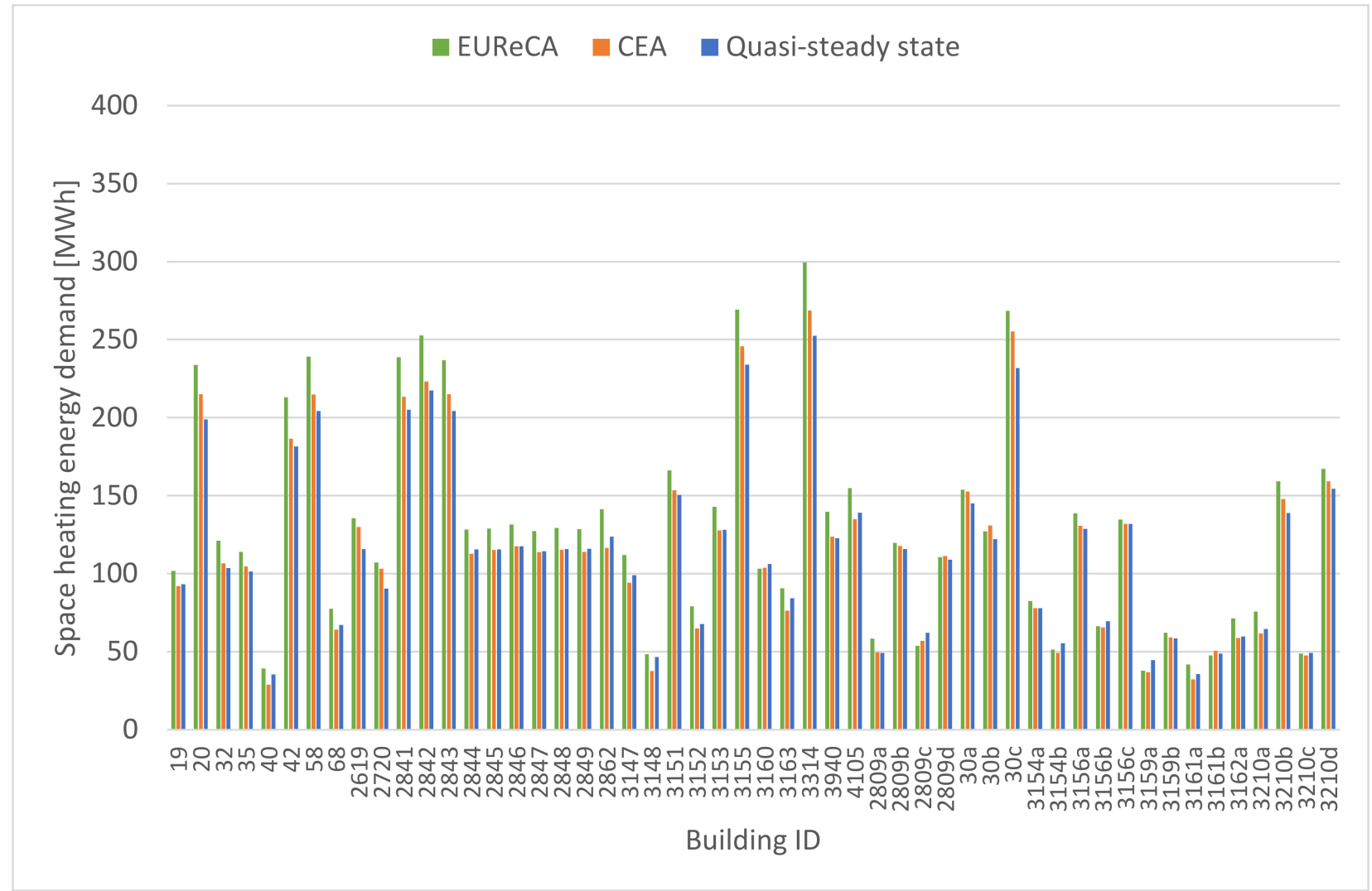

Figure 5. Estimation of the space heating energy demand in the heating period due to envelope transmission losses.

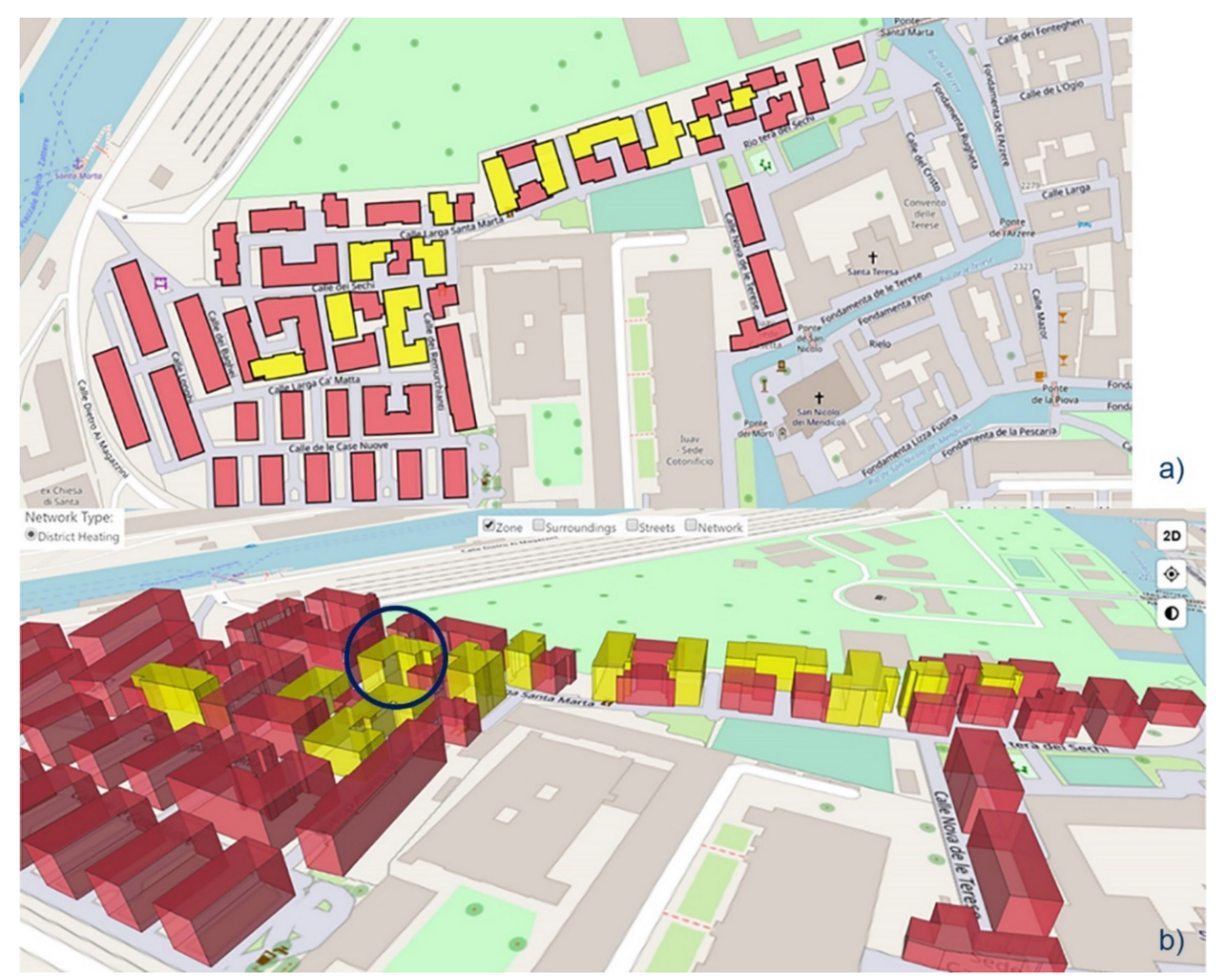

Figure 6. Geometric and thermal modeling of the building in the case study: (a) plant view, highlighted in yellow are the buildings presenting different heights within the same unit; (b) 3D view, focus on a sample building in case of contiguity and difference of levels. 


\subsection{Case SO2}

In this second simulation, the impact of ventilation losses is evaluated. In the quasisteady-state method, the ventilation refers to the heated volume and monthly average temperature, while in CEA, the rate of thermal losses due to ventilation is calculated according to following (Equation (5)) [44]:

$$
\phi_{v e}=H_{v e} \cdot\left(T_{a, \text { in }}-T_{a, \text { sup }}\right)[k W h] \text { where }=H_{v e}=C p_{a} \cdot A e \cdot\left(\dot{v}_{v e}+\dot{v}_{\text {inf }}\right)[k W h / K]
$$

where

$c p_{\text {air }}:$ volumetric heat capacity of air fixed at $1.2 \mathrm{~kJ} /\left(\mathrm{m}^{3} \mathrm{~K}\right)$;

$A_{e}$ : conditioned floor rea $\left(\mathrm{m}^{2}\right)$;

$v_{v e}$ : is the specific volumetric flow of fresh air required for air quality $\left(\mathrm{m}^{3} / \mathrm{h} \mathrm{m}^{2}\right)$;

$v_{\text {inf: }}$ is the specific infiltration flow rate of outside air $\left(\mathrm{m}^{3} / \mathrm{h} \mathrm{m}^{2}\right)$;

$T_{a, i n}$ : indoor air temperature $(\mathrm{K})$;

$T_{a, \text { sup }}$ : supply air temperature $(\mathrm{K})$.

Therefore, the calculation in CEA depends on the heated area per floor and the hourly temperature gap as well as the type of occupancy specifically and its schedule. The differences with EUReCA may be related to the different calculations performed, because the resistance-capacitance method is based on the heated volume, which is on average $3 \%$ lower compared to CEA (Figure 7).

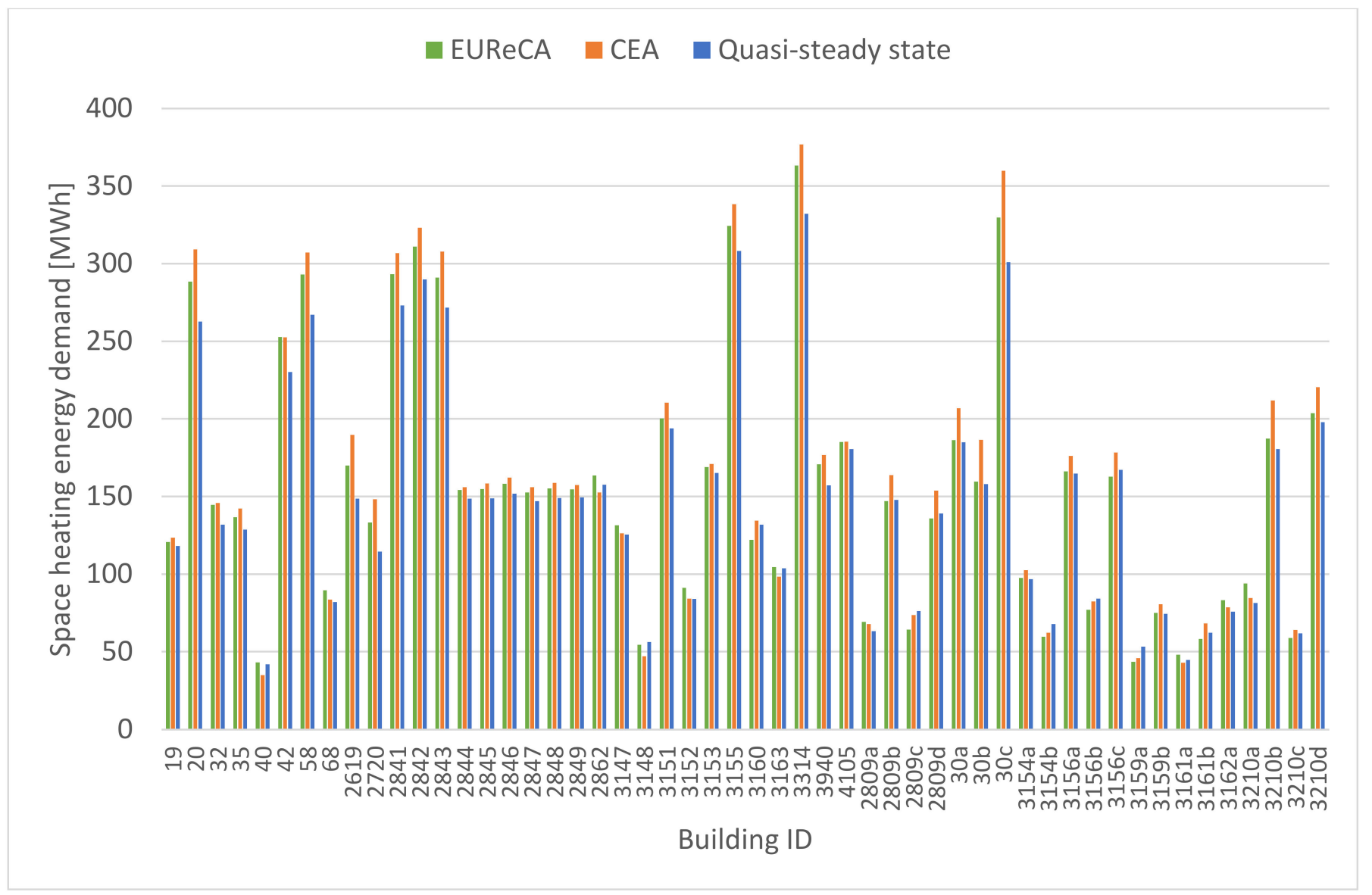

Figure 7. Evaluation of the space heating energy demand in the heating period considering transmission and ventilation losses. 


\subsection{Case $S 03$}

In the third simulation, case $\mathrm{S} 03$, the total heating demand of the district is calculated (Figure 8).

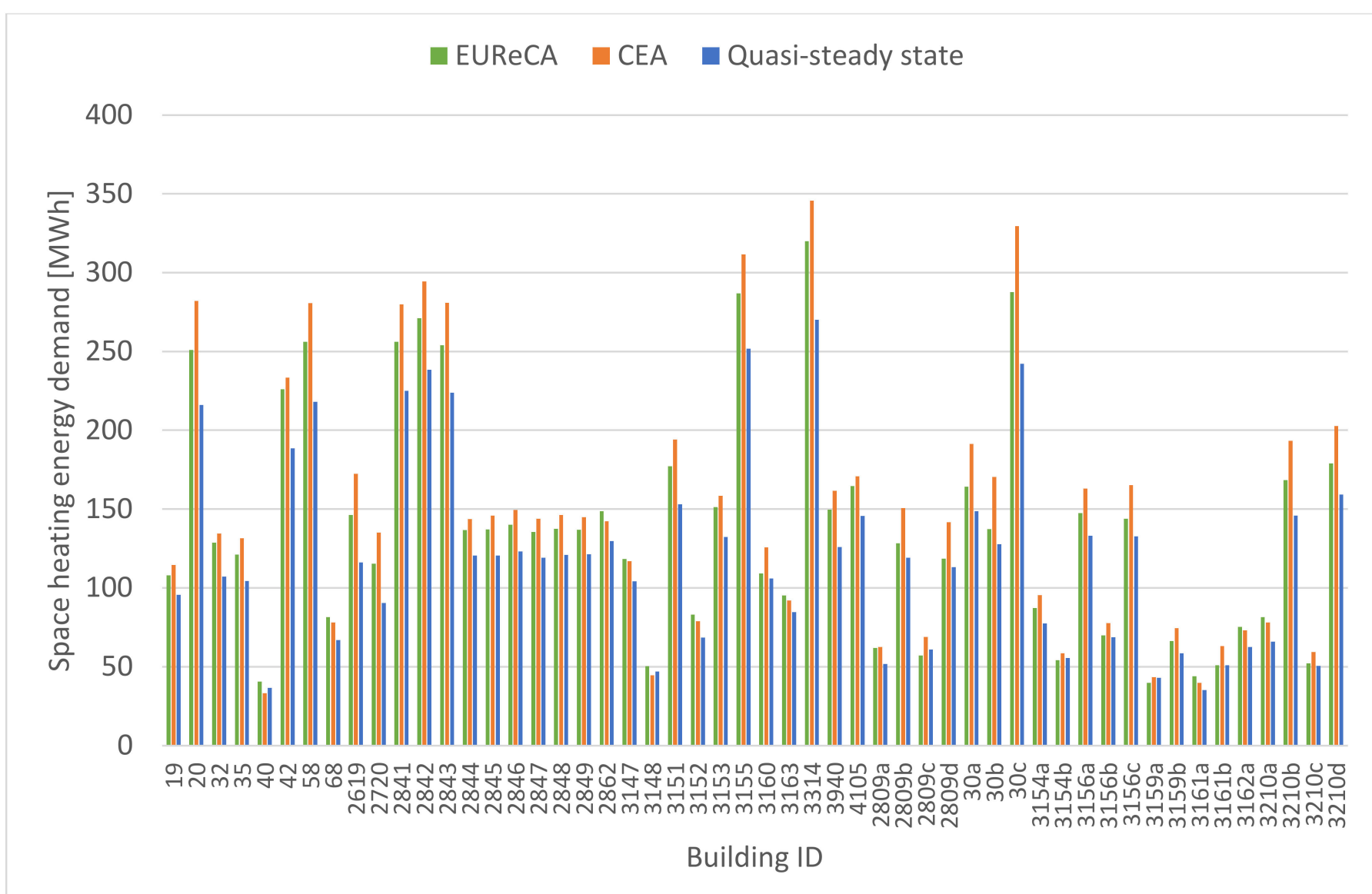

Figure 8. Evaluation of the space heating energy demand in the heating period considering the contribution of internal loads.

Both EUReCA and CEA overestimate the space heating energy demand at a singlebuilding scale, compared to the tool developed with an MS Excel spreadsheet. This difference is due to two main issues.

First of all, while CEA and EUReCA consider the mutual shading between the buildings included in the GeoJSON, the shading of the surrounding buildings is not considered in the spreadsheet. Therefore, solar gains are calculated for the entire period of exposure as if the buildings were not located in an urban context. Moreover, the 3D modeling used for dynamic state simulation affected the shading of the building towards itself for the same reasons already explained in Figure 6.

In addition, in the simplified tool, the geometry of individual buildings is based on the surface and perimeter of the footprint. The overall lateral external area, which is responsible for most of the transmission losses, is calculated according to the perimeter that does not consider adiabatic surfaces bounding adjacent buildings. On the other hand, the glazed area was calculated with a window-to-wall ratio (WWR) equal to $20 \%$, calibrated on the information collected with the survey on site.

The quasi-steady-state method underestimates the energy demand significantly compared to the dynamic tools, while the previous simulations presented similar results. The main difference is related to the implementation of internal loads because the usage factor considered in the standard has shown some critical results for historic buildings [78-80]. 


\subsection{Discussion}

To conclude, the comparison of the input and output data shows some differences in the assumption of data by CEA and EUReCA.

Concerning the geometrical input, the perimeter value used in the calculations is discretized by CEA, which excludes edges below a certain threshold length. It is assumed that the discretization is implemented to simplify the layouts from the shapefile or from the cadastral fil; however, the simplification affects the definition of other geometric and calculation inputs such as the heated volume and the overall lateral external area.

The two methods use different inputs for the calculation of the internal loads. MS Excel uses an average total value for the air-conditioned surface area, whereas CEA and EUReCA do not consider the number of apartments per building, using the occupancy density parameter provided by the EN 16798:2019-1 [73], and this implies a difference in value in internal gains. However, the results are similar and are considered acceptable given the small impact on the calculation of overall heating demand. In fact, occupancy heat gains related to hourly sensible and latent heat gain are due to occupancy rate.

Even though solar gains are calculated with different methods, the adoption of hourly or seasonal data implies that solar gains have a greater influence on the disparity in value impacting differently on the energy requirements for space heating.

Table 4 presents the results obtained and analyzed for the district level. Despite the differences highlighted at the single-building scale, in a broader perspective, both CEA and EUReCA show promising results compared to the quasi-steady-state method (percentages in blue) with the absence of infiltration and internal loads that implies the use of schedules. Case S02 includes a constant flow rate, evaluated based on the heated floor area in CEA, which increases the heating energy demand by $9 \%$ compared to MS Excel, while EUReCA is only $5 \%$ greater than the MS Excel spreadsheet because the calculation method is based on the volume, which is on average slightly smaller.

Table 4. Total district energy demand [MWh]: blue percentage compares to the quasi-steady-state method, red percentage compares the two dynamic tools.

\begin{tabular}{cccc}
\hline & $\begin{array}{c}\text { MS Excel Spreadsheet } \\
\text { [MWh] }\end{array}$ & $\begin{array}{c}\text { CEA } \\
\text { [MWh] }\end{array}$ & $\begin{array}{c}\text { EUReCA } \\
\text { [MWh] }\end{array}$ \\
\hline \multirow{3}{*}{ S01 } & 6018 & 6115 & 6707 \\
& & $(+2 \%)$ & $(+11 \%)$ \\
& \multirow{2}{*}{ S732 } & 8435 & 8083 \\
& & $(+9 \%)$ & $(+5 \%)$ \\
& \multirow{2}{*}{ S02 } & 7769 & $(-4 \%)$ \\
\hline \multirow{2}{*}{ S03 } & 6274 & $(+24 \%)$ & $(+33 \%)$ \\
& & & $(+7 \%)$ \\
\hline
\end{tabular}

The two dynamic tools calculate a significantly higher energy demand when including internal loads because they imply using specific operating schedules. On the other hand, the quasi-steady-state method implements constant loads throughout the day, thus increasing the contribution of internal loads and decreasing the need for space heating. Moreover, EUReCA splits sensible internal loads as radiant and convective, and their fraction depends on the equations provided by the EN ISO 13790:2008 Standard. In addition, the heat provided by the ideal system has been split in 50\% radiant and 50\% convective in EUReCA, justifying the differences compared to CEA.

When comparing the two dynamic tools (red percentage), the 5R1C model tends to overestimate the heating energy demand compared to CEA, except for case S02, with a difference of $2 \%$. However, this error is acceptable when dealing with large-scale simulation analysis because it is mainly related to the different input definitions and the calculation method. 


\section{Conclusions}

The paper analyzes the application of three methods for heating energy demands at the district level in order to understand and highlight the advantages and limitations of applying a quasi-steady-state method and dynamic approaches. The application results of a specific case study in Venice, the residential district of Santa Marta, lead to some final considerations.

The transmission heat losses are comparable, as expected, even if further analysis should estimate the contribution of thermal bridges not yet developed in the MS Excel spreadsheet. The calculation and the value of the infiltration losses reduce the gap between the two methods, even if the calculation formulas are different.

Calculating the solar heat gains separately shows their potential impact on the overall heating demand both at single-building and at district scales, since the quasi-steady-state calculation does not consider the mutual shading of the buildings and overestimates the contribution of solar gains for an average value of around $47 \%$.

Regarding the district simulation, simplified resistance-capacitance networks show a good prediction of the district energy demand, overestimating the energy demand at district level by $7 \%$ compared to other dynamic tools, thus demonstrating the accuracy and reliability of the proposed approach with a lower computational effort.

The application of the simplest quasi-steady-state method implemented in an MS Excel file could be useful for non-specialist users such as elected officials, politicians, or urban planners who have practical implications in the development of cities and should be able to have an overall idea of the possible strategies to plan sustainable districts.

Future developments are addressed to evaluate cooling demand and domestic hot water (DHW) at the district level to assess the summer energy use and to evaluate the redevelopment and replacement of systems according to the impact of DHW consumption.

The next step is to analyze the refurbishment of the whole neighborhood to improve the conditions of the building envelope and the installation of more efficient systems to reduce energy consumption and the associated global costs (investment and maintenance).

Author Contributions: Conceptualization, P.R. and A.Z.; methodology, T.D.M., L.T. and L.C.; software, T.D.M., L.T. and L.C.; validation, A.Z.; formal analysis, A.Z.; investigation, T.D.M., L.T. and L.C.; resources, T.D.M., L.T. and L.C.; data curation, T.D.M., L.T. and L.C.; writing-original draft preparation, T.D.M., L.T. and L.C.; writing—review and editing, T.D.M., L.T. and L.C.; visualization, P.R.; supervision, P.R. and A.Z.; project administration, P.R. and A.Z.; funding acquisition, P.R. and A.Z. All authors have read and agreed to the published version of the manuscript.

Funding: This research received no external funding.

Institutional Review Board Statement: Not applicable.

Informed Consent Statement: Not applicable.

Data Availability Statement: The data presented in this study are available on request from the corresponding author. The data are not publicly available due to privacy restrictions.

Conflicts of Interest: The authors declare no conflict of interest.

\section{References}

1. Tukker, A.; Huppes, G.; Guinée, J.; Heijungs, R.; de Koning, A.; van Oers, L.; Suh, S.; Geerken, T.; van Holderbeke, M.; Jansen, B.; et al. Environmental impact of products (EIPRO). Eur. Comm. Jt. Res. Cent. 2006, 303-308.

2. Eurostat Energy Database. Transport and Environment Indicators; Publications Office of the European Union: Luxembourg, 2018. [CrossRef]

3. Masha, R.T.; Houreld, N.N.; Abrahamse, H. Low-Intensity Laser Irradiation at $660 \mathrm{~nm}$ Stimulates Transcription of Genes Involved in the Electron Transport Chain. Photomed. Laser Surg. 2013, 31, 47-53. [CrossRef]

4. European Commission. EU Energy in Figures—Statistical Pocketbook; Publications Office of the European Union: Luxembourg, 2009. [CrossRef]

5. Balaras, C.A.; Droutsa, K.; Dascalaki, E.; Kontoyiannidis, S. Service life of building elements \& installations in European apartment buildings. In Proceedings of the 10DBMC International Conférence on Durability of Building Materials and Components, Lyon, France, 17-20 April 2005. [CrossRef] 
6. Piccardo, C.; Dodoo, A.; Gustavsson, L.; Tettey, U. Retrofitting with different building materials: Life-cycle primary energy implications. Energy 2019, 192, 116648. [CrossRef]

7. Mastrucci, A.; Marvuglia, A.; Benetto, E.; Leopold, U. A spatio-temporal life cycle assessment framework for building renovation scenarios at the urban scale. Renew. Sustain. Energy Rev. 2020, 126, 109834. [CrossRef]

8. ISTAT. Dati Censimento Della Popolazione. 2014. Available online: http:/ / dati-censimentopopolazione.istat.it/ (accessed on 5 May 2021).

9. ENEA. Energy Efficiency Trends and Policies in Italy; ENEA: Rome, Italy, 2018; pp. 1-37.

10. Bianco, V.; Scarpa, F.; Tagliafico, L.A. Analysis and future outlook of natural gas consumption in the Italian residential sector. Energy Convers. Manag. 2014, 87, 754-764. [CrossRef]

11. Toosi, H.A.; Lavagna, M.; Leonforte, F.; Del Pero, C.; Aste, N. Life Cycle Sustainability Assessment in Building Energy Retrofitting; A Review. Sustain. Cities Soc. 2020, 60, 102248. [CrossRef]

12. Su, S.; Li, X.; Zhu, Y. Dynamic assessment elements and their prospective solutions in dynamic life cycle assessment of buildings. Build. Environ. 2019, 158, 248-259. [CrossRef]

13. The European Parliament and the Council of the European Union. Directive 2010/31/EC of the European Parliament and of the Council of 19 May 2010 on the Energy Performance of Buildings, Official Journal of the European Union L315/1, Brussels, Belgium. 2010. Available online: https: / / eur-lex.europa.eu/legal-content/IT/ALL/?uri=celex:32010L0031 (accessed on 5 May 2021).

14. Paiho, S.; Ketomäki, J.; Kannari, L.; Häkkinen, T.; Shemeikka, J. A new procedure for assessing the energy-efficient refurbishment of buildings on district scale. Sustain. Cities Soc. 2019, 46, 101454. [CrossRef]

15. Doyle, M.D. Investigation of Dynamic and Steady State Calculation Methodologies for Determination of Building Energy Performance in the Context of the EPBD, Engineering. Ph.D. Thesis, Technological University Dublin, Dublin, Ireland, 2008. [CrossRef]

16. Kim, S.H. Selection of Energy Conservation Measures for Building Energy Retrofit: A Comparison between Quasi-steady State and Dynamic Simulations in the Hands of Users. KIEAE J. 2016, 16, 5-12. [CrossRef]

17. Corrado, V.; Fabrizio, E. Steady-State and Dynamic Codes, Critical Review, Advantages and Disadvantages, Accuracy, and Reliability. In Handbook of Energy Efficiency in Buildings; Butterworth-Heinemann: Oxford, UK, 2019; pp. 263-294. [CrossRef]

18. Castaldo, V.L.; Pisello, A.L. Uses of dynamic simulation to predict thermal-energy performance of buildings and districts: A review. Wiley Interdiscip. Rev. Energy Environ. 2017, 7, e269. [CrossRef]

19. Zakula, T.; Bagaric, M.; Ferdelji, N.; Milovanovic, B.; Mudrinic, S.; Ritosa, K. Comparison of dynamic simulations and the ISO 52016 standard for the assessment of building energy performance. Appl. Energy 2019, 254, 113553. [CrossRef]

20. Connolly, D.; Lund, H.; Mathiesen, B.; Leahy, M. A review of computer tools for analysing the integration of renewable energy into various energy systems. Appl. Energy 2010, 87, 1059-1082. [CrossRef]

21. Crawley, D.B.; Lawrie, L.K.; Winkelmann, F.C.; Buhl, W.; Huang, Y.; Pedersen, C.O.; Strand, R.K.; Liesen, R.J.; Fisher, D.E.; Witte, M.J.; et al. EnergyPlus: Creating a new-generation building energy simulation program. Energy Build. 2001, 33, 319-331. [CrossRef]

22. Ratnasari, L.D.; Sangadji, S.T.M.T.S.; Safitri, S.T.M.T.E. Evaluation of energy consumption with energyplus simulation in office existing buildings. AIP Conf. Proc. 2020, 2296, 020031. [CrossRef]

23. Lee, S.W.; Qian, X.; Garcia, S. An analysis of integrated ventilation systems with desiccant wheels for energy conservation and IAQ improvement in commercial buildings. Int. J. Bio-Urban. 2013, 105-124. Available online: https:/ /scholar.google.com/citations? view_op=view_citation\&hl=en\&user=MnB9KIAAAAAJ\&citation_for_view=MnB9KIAAAAAJ:u-x6o8ySG0sC (accessed on 15 July 2021).

24. Rhodes, J.D.; Gorman, W.H.; Upshaw, C.R.; Webber, M.E. Using BEopt (EnergyPlus) with energy audits and surveys to predict actual residential energy usage. Energy Build. 2015, 86, 808-816. [CrossRef]

25. Ligade, J.; Sebastian, D.; Razban, A. Challenges of creating a verifiable building energy model. ASHRAE Trans. 2019, 125, 20-28.

26. Qian, X.; Lee, S.W. The Design and Analysis of Energy Efficient Building Envelopes for the Commercial Buildings by MixedlevelFactorial Design and Statistical Methods. In Proceedings of the ASEE Middle Atlantic American Society of Engineering Education, Swarthmore, PA, USA, 14-15 November 2014.

27. Sartor, K.; Quoilin, S.; Dewallef, P. Simulation and optimization of a CHP biomass plant and district heating network. Appl. Energy 2014, 130, 474-483. [CrossRef]

28. Frayssinet, L.; Merlier, L.; Kuznik, F.; Hubert, J.-L.; Milliez, M.; Roux, J.-J. Modeling the heating and cooling energy demand of urban buildings at city scale. Renew. Sustain. Energy Rev. 2018, 81, 2318-2327. [CrossRef]

29. Happle, G.; Fonseca, J.A.; Schlueter, A. A review on occupant behavior in urban building energy models. Energy Build. 2018, 174, 276-292. [CrossRef]

30. Mosteiro-Romero, M.; Hischier, I.; Fonseca, J.A.; Schlueter, A. A novel population-based occupancy modeling approach for district-scale simulations compared to standard-based methods. Build. Environ. 2020, 181, 107084. [CrossRef]

31. Bollinger, L.A.; Evins, R. HUES: A holistic urban energy simulation platform for effective model integration. In Proceedings of the International Conference CISBAT 2015 Future Buildings and Districts Sustainability from Nano to Urban Scale, Lausanne, Switzerland, 9-11 September 2015; pp. 841-846.

32. Allegrini, J.; Orehounig, K.; Mavromatidis, G.; Ruesch, F.; Dorer, V.; Evins, R. A review of modelling approaches and tools for the simulation of district-scale energy systems. Renew. Sustain. Energy Rev. 2015, 52, 1391-1404. [CrossRef] 
33. Keirstead, J.; Jennings, M.; Sivakumar, A. A review of urban energy system models: Approaches, challenges and opportunities. Renew. Sustain. Energy Rev. 2012, 16, 3847-3866. [CrossRef]

34. Bourdic, L.; Salat, S. Building energy models and assessment systems at the district and city scales: A review. Build. Res. Inf. 2012, 40,518-526. [CrossRef]

35. Plan4DE. Available online: http:/ / plan4de.ssg.coop/ (accessed on 8 July 2021).

36. EXCEED. Available online: https:/ / dashboard.exceedproject.eu/ (accessed on 8 July 2021).

37. Toolbox. Available online: https:/ / www.hotmaps.eu/map (accessed on 8 July 2021).

38. Zhang, X.; Strbac, G.; Shah, N.; Teng, F.; Pudjianto, D. Whole-System Assessment of the Benefits of Integrated Electricity and Heat System. IEEE Trans. Smart Grid 2018, 10, 1132-1145. [CrossRef]

39. Fonseca, J.A. Energy Efficiency Strategies in Urban Communities: Modeling, Analysis and Assessment. Ph.D. Thesis, ETH Zurich, Zurich, Switzerland, 2016. [CrossRef]

40. Fonseca, J.A.; Thomas, D.; Willmann, A.; Elesawy, A.; Schlueter, A. The City Energy Analyst Toolbox V0.1. In Proceedings of the Sustainable Built Environment (SBE) Regional Conference, Zurich, Switzerland, 15-17 June 2006. [CrossRef]

41. Romano, P.; Prataviera, E.; Carnieletto, L.; Vivian, J.; Zinzi, M.; Zarrella, A. Assessment of the Urban Heat Island Impact on Building Energy Performance at District Level with the EUReCA Platform. Climate 2021, 9, 48. [CrossRef]

42. Prataviera, E.; Romano, P.; Carnieletto, L.; Pirotti, F.; Vivian, J.; Zarrella, A. EUReCA: An open-source urban building energy modelling tool for the efficient evaluation of cities energy demand. Renew. Energy 2021, 173, 544-560. [CrossRef]

43. Vivian, J.; Zarrella, A.; Emmi, G.; De Carli, M. An evaluation of the suitability of lumped-capacitance models in calculating energy needs and thermal behaviour of buildings. Energy Build. 2017, 150, 447-465. [CrossRef]

44. Comité Europeo de Normalización. ISO 13790:2008 Energy Performance of Buildings: Calculation of Energy Use for Space Heating and Cooling (ISO 13790:2008); CEN: Brusseles, Switzerland, 2008.

45. Fonseca, J.A.; Schlueter, A. Integrated model for characterization of spatiotemporal building energy consumption patterns in neighborhoods and city districts. Appl. Energy 2015, 142, 247-265. [CrossRef]

46. Fonseca, J.A.; Nguyen, T.-A.; Schlueter, A.; Marechal, F. City Energy Analyst (CEA): Integrated framework for analysis and optimization of building energy systems in neighborhoods and city districts. Energy Build. 2016, 113, 202-226. [CrossRef]

47. Zarrella, A.; Prataviera, E.; Romano, P.; Carnieletto, L.; Vivian, J. Analysis and application of a lumped-capacitance model for urban building energy modelling. Sustain. Cities Soc. 2020, 63, 102450. [CrossRef]

48. Weather Data I EnergyPlus. Available online: https:/ / www.energyplus.net/weather (accessed on 18 March 2021).

49. Ente Nazionale Italiano di Unificazione. UNI/TS 11300_Part 1: Evaluation of Energy Need for Space Heating and Cooling; UNI: Milan, Italy, 2014.

50. Mora, T.D.; Peron, F.; Romagnoni, P.; Almeida, M.; Ferreira, M. Tools and procedures to support decision making for cost-effective energy and carbon emissions optimization in building renovation. Energy Build. 2018, 167, 200-215. [CrossRef]

51. Thomsen, K.E.; Rose, J.; Mørck, O.; Jensen, S.; Østergaard, I.; Knudsen, H.N.; Bergsøe, N.C. Energy consumption and indoor climate in a residential building before and after comprehensive energy retrofitting. Energy Build. 2016, 123, 8-16. [CrossRef]

52. Ministro della Salute, Ministro dell'Ambiente, Ministro delle Infrastrutture, Decreto Ministeriale 26 August 2015, Applicazione Delle Metodologie di Calcolo Delle Prestazioni Energetiche e defi Nizione delle Prescrizioni e dei Requisiti Minimi Degli Edifici. 2015. Available online: https:/ / www.gazzettaufficiale.it/eli/gu/2015/07/15/162/so/39/sg/pdf (accessed on 5 May 2021).

53. Comitato Termotecnico Italiano CTI, Archivi Anni Tipo Climatici. 2015. Available online: https:// shop.cti2000.it/ (accessed on 5 May 2021).

54. CEN (European Committee for Standardization). EN ISO 15927-4: 2005-Hygrothermal Performance of Buildings-Calculation and Presentation of Climatic Data-Part 4: Hourly Data for Assessing the Annual Energy Use for Heating and Cooling; CEN: Brusseles, Switzerland, 2005.

55. Italian Organisation for Stardardisation (UNI). UNI 10349-1:2016, Heating and Cooling of Buildings—Climatic Data-Part 1: Monthly Means for Evaluation of Energy Need for Space Heating and Cooling and Methods for Splitting Global Solar Irradiance into the Direct and Diffuse Parts and for Calculate; CEN: Brusseles, Switzerland, 2016.

56. Decreto del Presidente della Repubblica. Decreto del Presidente della Repubblica n. 412 del 26 agosto 1993, "Regolamento Recante Norme per la Progettazione, l'installazione, l'esercizio e la Manutenzione Degli Impianti Termici Degli Edifici ai Fini del Contenimento dei Consumi di Energia, in att; CEN: Brusseles, Switzerland, 1993.

57. Il Presidente della Repubblica. Italian Law n.74/2013, Gazz. Uff. 27 Giugno 2013, n. 149. 2013, pp. 1-11. Available online: http:/ / www.energia.provincia.tn.it/binary/pat_agenzia_energia/dpr74-2013.pdf (accessed on 5 May 2021).

58. UNI Ente Nazionale Italiano di Unificazione. UNI/TS 11300; UNI Ente Nazionale Italiano di Unificazione: Milano, Italy, 2008.

59. Legge 31 Maggio 1903, n. 254, "Sulle case popolari," Gazz. Uff. (1903). Available online: https:/ /www.gazzettaufficiale.it/atto/ serie_generale / caricaDettaglioAtto / originario?atto.dataPubblicazioneGazzetta=1903-07-08\&atto.codiceRedazionale=003U025 4 (accessed on 19 February 2020).

60. L'ATER di Venezia e la sua Storia I ATER Venezi. Available online: https://web.archive.org/web/20150114032956/http:/ / www.atervenezia.it/informazioni-generali/la-storia-il-profilo-operativo-e-le-cifre-dellente/later-di-venezia-e-la-sua-storia / (accessed on 19 February 2020).

61. Azienda Territoriale per l'Edilizia Residenziale L'ATER di Venezia e la sua Storia. Available online: https://www.atervenezia.it/ ente/later-di-venezia-e-la-sua-storia / (accessed on 19 February 2020). 
62. Case Dello IACP a Santa Marta, già Quartieri “Benito Mussolini" e "SADE"|Conoscere Venezia. Available online: https: / / www.conoscerevenezia.it/? $p=43647$ (accessed on 19 February 2020).

63. Venice EPW Weather Data. Available online: https://energyplus.net/weather-location/europe_wmo_region_6/ITA//ITA_ Venezia-Tessera.161050_IGDG (accessed on 19 February 2020).

64. Murano, G.; Corrado, V.; Dirutigliano, D. The new Italian Climatic Data and their Effect in the Calculation of the Energy Performance of Buildings. Energy Procedia 2016, 101, 153-160. [CrossRef]

65. CEN (European Committee for Standardization). EN ISO 15927-6:2007 Hygrothermal Performance of Buildings-Calculation and Presentation of Climatic Data_Part 6: Accumulated Temperature Differences (Degree-Days); CEN: Brusseles, Switzerland, 2007; pp. 1-13.

66. Quantum GIS. Available online: https://www.qgis.org/en/site/ (accessed on 28 January 2021).

67. Open Street Map. Available online: https://www.openstreetmap.org/ (accessed on 28 January 2021).

68. Mutani, G.; Vicentini, G. Analisi del fabbisogno di energia termica degli edifici con software geografico libero. Il caso studio di Torino. La Termotec. 2013, 6, 63-67.

69. Agugiaro, G. Energy planning tools and CityGML-based 3D virtual city models: Experiences from Trento (Italy). Appl. Geomat. 2015, 8, 41-56. [CrossRef]

70. Google Maps. Available online: https:/ / www.google.com/maps/@45.4387765,12.3380271,13.26z?hl=en-GB\&authuser=0 (accessed on 27 February 2020).

71. Bing Maps-Directions, Trip Planning, Traffic Cameras \& More. Available online: https://www.bing.com/maps (accessed on 27 February 2020).

72. Barbiani, E. Edilizia Popolare a Venezia; Mondadori Electa: Milano, Italy, 1983.

73. European Committee for Standardization-CEN. BS EN 16798_Energy Performance of Buildings_Ventilation for Buildings-Part 1: Indoor Environmental Input Parameters For Design And Assessment of Energy Performance Of Buildings Addressing Indoor Air Quality, Thermal Environment, Lighting And Acoustic; CEN: Brussels, Belgium, 2019.

74. Fu, P.; Rich, P.M. A geometric solar radiation model with applications in agriculture and forestry. Comput. Electron. Agric. 2002, 37, 25-35. [CrossRef]

75. Esri Support ArcMap 10.2 (10.2.1, 10.2.2). Available online: https:/ / support.esri.com/en/products/desktop/arcgis-desktop/ arcmap/10-2-2 (accessed on 8 July 2021).

76. Reinhart, C.F. DAYSIM Advanced Daylight Simulation Software; MITPress: Boston, MA, USA, 2021; Available online: http: / / daysim.ning.com (accessed on 5 May 2021).

77. Arasteh, D.; Kohler, C.; Griffith, B. Modeling Windows in Energy Plus with Simple Performance Indices; Lawrence Berkeley National Lab: Berkeley, CA, USA, 2009. [CrossRef]

78. Cecchinato, L.; Romagnoni, P.; Schibuola, L. Building heating requirement calculation: A critical analysis of the new European standards. Int. J. Ambient. Energy 2000, 21, 21-30. [CrossRef]

79. Magrini, A.; Magnani, L.; Pernetti, R. The effort to bring existing buildings towards the A class: A discussion on the application of calculation methodologies. Appl. Energy 2012, 97, 438-450. [CrossRef]

80. Corrado, V.; Fabrizio, E. Il significato del fattore di utilizzazione nel calcolo semplificato del fabbisogno termico degli edifici: Aspetti teorici e applicativi. In Proceedings of the AiCARR “Certificazione Energetica: Normative e Modelli di Calcolo per il Sistema Edificio-Impianto Posti a Confronto", Bologna, Italy, 16 October 2008. 